\title{
Sibel Filminin Ekonomi Politiği: Yapım Sürecinin Yansımaları
}

\section{Mesut COŞKUN*}

$\ddot{O} \mathbf{z}$

Sinema endüstrisi içinde, bağımsız filmler genel ve basit bir tanımlama ile yönetmenin finans desteğini genellikle kendi sağladığı, herhangi bir yapımcıya bağlı kalınmayan, gişe kaygısı gütmeyen, sanat adına yapılan filmler olarak kabul edilmektedir. Çalışma konumuz olan Sibel filmi, Eurimages desteğiyle çekilen dört farklı ülkenin destek verdiği ortak yapım bir sinema filmidir.

Çalışma Sibel filminin yapım sürecine ve üretim koşullarına odaklanmıştır. Bunun için filmde çalışan profesyonellerle ve film yapım sürecinde katkıları bulunan Kuşdili köy muhtarı ve ıslık (kuşdili) öğretmeni ile yüz yüze yarı yapılandırılmış sorularla görüşme yapılmıştır. Bu görüşmelerle, çok dilli ve çok kültürlü ortak yapım ekibiyle birlikte, Kuşköy sakinlerinin, ekonomik, sosyal ve kültürel iletişimi de analiz edilmeye çalışılmışıtır.

Filmin ön yapım aşaması olan fikrin, senaryoya dönüşmesi ve çekime karar verilmesinden, gösterimine kadar olan süreç ve bu süreçte karşılaşılan sorunlar, üretilen çözümler ile hem Türkiye'ye, hem örnek filme özgü koşullar irdelenmeye çalışılmıştır.

Anahtar Sözcükler: Bağımsız Sinema, Küreselleşme, Ekonomi-Politik, Ortak Yapım, Yapım Süreci

\section{Political Economy of Sibel Motion Picture: Reflections of the Production Process}

\begin{abstract}
Within the cinema industry, in a general and simple definition, independent films are generally considered as films provided by the director's own financial support, not being tied to any producers, not worrying about box Office success and made for the sake of the art. The Sibel, our subject of study, is a co-produced feature film supported by four different countries and shot with the support of Eurimages.

The study has focused on the production process and production conditions of the Sibel film. Therefore; with face-to-face semi-structured questions, interviews were had with the professionals working in the film, the village headman of Kuşdili and the teacher taeching whistle (Kuşdili) who made contributions in the film making process. In these interviews, the economic, social and cultural communication of the residents of Kuşköy was also analyzed together with the multilingual and multicultural co-production team.

Conditions particular to both Turkey and sample film have been tried to study with the process, from the time when film's the idea of the pre-production stage has turned into a screenplay and its shooting has been determined to its screening, the problems encountered and the solutions produced in this process.
\end{abstract}

Keywords: Independent Cinema, Globalisation, Political Economy, Co-Production, Production Process

Geliş/Received: 10.09 .2020

Kabul/Accepted: 30.09 .2021

- Bu çalışma için, Giresun Üniversitesi Bilimsel Araştırma ve Yayın Etiği Kurulu'nun 12.03.2020 tarih ve 44079388-34 sayılı toplantısı ile etik kurul izni alınmıştır.

\footnotetext{
* Dr. Öğr. Üyesi Giresun Ün., Tirebolu İletişim Fak., RTS Bölümü, mesut.coskun @ giresun.edu.tr, ORCID ID: 0000-00022437-6817.

(Makale Türü: Araştırma Makalesi)
} 


\section{Sibel Filminin Ekonomi Politiği: Yapım Sürecinin Yansımaları}

\section{Giriş}

Bir kültür üretimi ve ideolojik yeniden üretim alanı olarak sinemanın endüstrileşmesi filmin üretim, dağıtım ve tüketim süreçlerinin karmaşık ve girift ilişkilerini ortaya koymayı gerektirmektedir (Dağtaş, Aydın. ve Yılmaz, 2018:186). Sinema çok boyutlu (ekonomik, siyasi, kültürel, teknolojik, sanatsal vb.) bir olgudur. Sinema konusunda yapılacak tek boyutlu bir çözümleme sinema endüstrisini anlamada yetersiz kalacaktır (Dağtaş, Aydın. ve Yılmaz: 2018:188).

Makineler ve donanımlar olmadan filmler çekilemez ve gösterilemez. Film yapmak sadece teknik olanaklara bağlı da değildir, bunun yanında alanlarında profesyonel birçok insanın işbirliği gerekir. Filmler, toplumsal ve ekonomik bağlamlarıyla ilişkilidir. Toplumsal ilişkiler ve ekonomik yatırım miktarı filmlerin yapımında ve gösteriminde başat rol oynar (Bordwell ve Thompson: 2009, 1451).

Sinema endüstrisi, yapım öncesi, yapım ve yapım sonrası süreçleriyle ekonomik, sosyal, siyasal, toplumsal ve kültürel bir süreçtir. Kültürel bir eylem olduğu için ekonomik üretim süreci diğer sektörlerden bazı yönleriyle ayrılmaktadır. Diğer endüstrilerde ortaya çıkan ürünün kullanım değeri ve değişim değerleri, maddi koşullar ile sınırlıyken, kültürel üretim, sanatsal bir değer de içermektedir. $\mathrm{Bu}$ nedenle, sinemanın bu farklı yönü kuramsal olarak tartışma konusu olmuştur.

Bu çalışma, Giresun ili, Çanakçı ilçesi, Kuşköy'de, yönetmenliği ve senaristliği Çağla Zencirci ve Guillaume Giovanetti tarafindan gerçekleştiren 2018 çıkışl, ilk gösterimi 3 Ağustos 2018'de Locarno Film Festivali'nde gerçekleştirilen Euroimages destekli Sibel isimli ortak yapım olan dramatik filmin üretim aşamaları, yapım sürecini analiz etmek amacıyla yapılmıştır. Bu amaç doğrultusunda yapım sürecine ekonomi-politik bir yaklaşım gösterilmiştir.

Çalışmamızın sorunsalı; Film endüstrisinin en önemli aşamalarından birisi olan yapım aşaması, film bütçesi, çekim takvimi, profesyonellerin nicel/nitel özellikleri ve çekim atmosferinin fiziksel/ruhsal koşulları ile kısıtladığı koşullarla biçimlenen oldukça zahmetli bir süreç olduğudur. Yapım süreci sonunda ortaya çıkan kültürel ürün, fikir aşamasından başlayarak tüm faktörlerden etkilenmektedir. Ortaya çıkan filmin, ön yapım, yapım ve yapım sonrası koşulları filmin teknik, estetik, sanatsal, ekonomik tüm sonuçlarıyla ilişkilidir.

İnsanların yaşayışları, yaşanmış tecrübeleri, davranışları, duyguları, hisleri aynı zamanda toplumsal işleyiş, sosyal hareketler, kültürel olaylar ve uluslararasındaki ilişkiler nitel araştırmaların konusu olabilir (Yıldırım, 2010 : 80). Bu çalışma betimsel bir çalışmadır. Betimsel yöntemler, ilgilenilen ve araştırılmak istenen problemin mevcut var olan durumunu ortaya koymaya yöneliktir. $\mathrm{Bu}$ yöntemlerin en temel özelliği, mevcut hâlihazır durumu kendi koşulları içerisinde ve olduğu gibi çalışmaktır. Betimsel araştırma, çalışılan konunun mevcut durumuna ilişkin hipotezler test etmek için veya sorulara cevap bulmak için veriler toplamayı gerektirir (Yıldırım, 2010: 86). 
Çalışma Sibel filminin yapım sürecine ve üretim koşullarına odaklanmıştır. Filmin ön yapım aşaması olan fikrin, senaryoya dönüşmesi ve çekime karar verilmesinden, gösterimine kadar olan süreç ve bu süreçte karşılaşılan sorunlar, üretilen çözümler ile hem Türkiye’ye, hem örnek filme özgü koşullar irdelenmeye çalışılmıştır. Bunun için filmde çalışan profesyonellerle yüz yüze (Çağla Zencirci ve Osman Özcan ile elektronik postayla) derinlemesine görüşme tekniğiyle görüşülmüştür.

\section{Küreselleșme ve Sinema Endüstrisi}

Küreselleşmeye dair farklı yaklaşımlar küreselleşmeyi tanımlarken iletişim ve ulaşım teknolojilerindeki gelişmelerin zaman ve uzam anlayışı arasındaki ilişkiyi değiştirmesine vurgu yapmışlardır (Tüzün, 2011: 6). Ekonomik, sosyal ve kültürel alanlarda dünya ölçeğinde yaşanan gelişmeleri, emeğin, sermayenin, bilimsel ve sanatsal üretimin ulusal sınırları aşarak dolaşıma ve etkileşime geçmesini ifade eden küreselleşmenin yol açtığı en önemli değişimlerden biri, farklı sektörler ya da yapılar arasındaki geçirgenlik, iç içe geçmişliktir (Özen ve Çelenk, 2006: 69).

Küresel açıdan sinema filmi üreten kuruluşlar büyük işletmelerdir. Bu şirketler, sahipleri açısından önemli gelir ve kâr kaynağıdır. Bu bağlamda, sinema endüstrisi hem büyük sermaye sahipliğini gerektirir hem de bu sektörde faaliyet gösteren şirketler bu etkinlikleri sonucunda zenginleşmektedir. Küreselleşme sürecinde film şirketleri daha da büyümüştür. Dünya çapında sinemaya bakıldığında, uluslararası sinemanın tekelci bir yapıda olduğu gözlemlenmektedir (Dağtaş, Aydin, ve Y1lmaz, 2018: 192).

Sözü edilen durum, üretim ve dağıtım maliyetlerini düşürerek bu alanda faaliyet gösteren şirketlerin daha çok kâr etmelerini sağlamaktadır. Çünkü bağımsız yapımcıların büyük stüdyolarla rekabet etmesi mümkün değildir. Büyük stüdyolar hem üretim ve dağıtımı kontrol etmekte hem de daha çok film üretmektedir. Bu alanda Amerikan ulus-aşırı holdingleri egemendir. Sinema filmi üreten şirketler, çokuluslu holdinglerin yan kuruluşlarıdır. Ulus-aşırı sinema pazarını kontrol eden firmalara bakıldığında, bunların mülkiyet açısından yoğunlaştıkları ve bu alanda çeşitliliğin azaldığı görülmektedir. Sinema sektöründe Disney, AOL-Time Warner, Paramount, Universal, Fox, Tri Star, Columbia, MGM gibi sayılı firmalar egemendir (Dağtaş, Aydın, ve Yılmaz, 2018: 192).

Toplumsal düşünüme hareket kazandıran sinema ister popüler ister bağımsız anlatı örneklerinden oluşsun benzer yapım koşullarına tabi olur. Bu sebeple film endüstrisinin oluşmasını sağlayan en önemli yapıların yapım, dağıtım ve gösterim olduğu söylenebilir. Filmlerin seyirciyle buluşmasını, başarı grafiğini ve pazarda yer elde etmesini sağlayan birbiriyle sıkı ilişkiler içerisinde olan bu yapılar, dünyanın farklı endüstrilerinde farklı politikalarla düzenlenmektedir (Bordwell ve Thompson, 2009: 1-15).

\section{Ana Akım Sinema ve Bağımsız Sinema}

Sinema başlangıcından bu yana farklı akımlar, yaklaşımlar ile üretimini sürdürmüştür. Bir 


\section{Sibel Filminin Ekonomi Politiği: Yapım Sürecinin Yansımaları}

taraftan tecimsel üretimin stüdyo sistemi (Hollywood Sineması) ile sürdüren Amerikan sistemi diğeri de sanatsal ve auteur (yönetmen) ağırlıkla üretimini sürdüren Avrupa sineması. Sinema Nedir? isimli kitabında ünlü yazar Andre Bazin, inandırıcılığını gerçeklik üzerine kuran filmler ile filmi imge, plastik yapaylık ve sayısız araç üzerinden yapılandıran filmler olarak ikiye ayırmaktadır (Clarke, 2012: 20).

Bağımsız sinema, ana akım sinemadan film yapım süreci, bütçe, içerik ve sinema amaçlarıyla farklılıklar göstermektedir. Bağımsız filmlerin öncelikli amacı gişe başarısı değildir ve genellikle ana akım filmlerden farklı olarak sanatsal içerik, anlatım biçimi, cesur bir stil ve sıra dışı konularla ayrılırlar (Akser, 2015, s. 134). Aynı zamanda, Yannis Tzioumakis'in Hollywood Sinema endüstrisi ile Amerikan Bağımsız sineması ilişkisinde vurguladığı gibi en büyük fark film yapım süreçleridir. Tekelleşmiş büyük holding yapımlarına göre bağımsız filmler düşük bütçeli, genç film yapımcıları tarafından yapılan cesur, yenilikçi filmlerdir (Tzioumakis, 2006: 1-14).

Film festivallerinde ödül kazanmak, filmin saygınlığı bağımsız sinema yapımcı ve yönetmenleri için önceliklidir. $\mathrm{Bu}$ festivallerde genellikle, belirli, seçkin izleyiciye seslenirler. Bu tercih sinema endüstrisinin ekonomi-politik yapısıyla ilgili olduğu gibi, bağımsız sinemanın yaşama, insan varlığına ve mevcut duruma bakışıyla da doğrudan ilgilidir. Geniş bir yaklaşımla, sanatsal, yönetmen filmleri, deneysel, sınırları zorlayan çalışmaların yanı sıra kimlik tabanlı, sosyal olarak bilinçli filmlerin hepsi bağımsız sinema şemsiyesi altına girer (Akser, 2015: 134).

\section{Türkiye'de Bağımsız Sinema}

Türk Sineması 20.yüzyıl sürecinde birçok değişime uğramıştır. Geç Yeşilçam sineması 1970'lerde Türkiye'nin sosyal, kültürel ve ekonomik şartlarını konu alarak izleyiciye ulaşmıştır. O yıllar, yapımcıların yıldız sistemi denilen Türkiye'nin kendi koşullarına uygun bir film yapım sisteminin geçerli olduğu yıllar olmuştur. 1971-1981 arası Türk politik sinemasını Yılmaz Güney’in başı çektiği filmler temsil etmiştir. Güney'in Umut ve 1982 Cannes Altın Palmiye ödülünü kazandığı Yol filmleri döneme damga vurmuştur. 12 Eylül 1980 askeri darbesinin yasakçı zihniyeti politik filmlerin yapılmasına uygun ortam bırakmamıştır. Zeki Ökten ve Şerif Gören askeri rejimin vahşetini sergileyen filmler yapmıştır. Diğerleri Ömer Kavur gibi içe dönük kişisel sinema yapma yoluna gitmiştir (Akser, 2018: 163).

Uzun bir süre sonra, Türk sinemasının canlanması 1997 yılı yapımı Eşkıya filmiyle geldi. 1997 yılından itibaren Türk sineması dünya çapında festivaller ve yerli izleyicisini tekrar kazanma sürecine girmiştir. Nuri Bilge Ceylan, Reha Erdem ve Semih Kaplanoğlu gibi yönetmenler Avrupa'da festivallerden ödüller getirmiş̦tir. Yeni dönem filmleri yeni bir anlayışı temsil etmektedir. Kişisel psikozlar, Türk toplumundaki Kürt azınlığı gibi kültürel çatışmalar, LGBT grupları ve kadınların ses vermesi gibi kültürel çatışmalara yeni dönem sineması yeni bir ışık tutmuştur (Akser, 2018: 164).

1980 yılından sonra, devletin yeniden düzenlediği kurallar, sermaye birikimini artırma amacına 
yönelik birçok kamu kuruluşunun yanı sıra, kamu yayıncılığı alanının da özelleştirilmesini beraberinde getirmiştir. "1980’li yıllardan itibaren tüm dünyaya yayılmış olan özelleştirme yönündeki uygulamalar, medyanın ve daha özelde sinema sektörünün giderek büyük şirket yapıları içerisine dâhil olmalarıyla sonuçlanmıştır” (Dağtaş, Aydın, ve Yılmaz, 2018: 196).

Bu dönemde 1987 yılında Yabancı Sermaye Yasası'nda yapılan bir değişikle birlikte yabancı şirketlerin Türkiye'de film gösterim ve dağıtım hakkı elde eder. Bu gelişme 1987'de Amerikan şirketlerinden Warner Bros'un, 1989'da Universal, Paramount ve Walt Disney'in dağıtım hakkına sahip olan United International Pictures'1n (UIP) ve 2014'de 20th Century Fox'un dağıtımını yapan (2014'e kadar dağıtımı Özen Film yapmıştır) The Moments Entertainment'ın (TME) Türkiye pazarına girmesine ve sektörde egemenlik kazanan yabancı şirketler olmasını sağlar. 2011 yılında AFM'nin Mars Group tarafından devralınması ile Mars'ın pazardaki etki gücü oldukça belirgin bir artış gösterir ve egemenlik dengesi bozulur. Türkiye genelinde 61 AVM projesinin 33 sinema salon işletmesini Mars Group alır (Birincioğlu, 2019: 85).

Türk Sinema endüstrisinin içinde temel problem, üretim, dağıtım ve gösterim aşamalarının sorunlu olması nedeniyle üretilen filmler yeterli gösterim olanağı bulamamaktadır. (Birincioğlu, 2019: 83). Bağımsız filmlerin gösterim sorunu konusunda, bağımsız filmlerin dağıtımcısı Başka Sinema Dağıtım ve Kariyo\&Ababay Vakfi işbirliğiyle 2013 yılından beri anlaşmalı olduğu sinema salonlarında bağımsız film gösterimi yapmaktadır (Midilli, 2016: 1430). İstanbul ve Ankara'nın belli salonlarında başlangıçta gösterim yapabilen Başka Sinema 2020 yılı ile birlikte gösterim yaptığı şehirler arasında İstanbul, Ankara, Eskişehir, İzmir, Bursa, Antakya, Muğla, Konya, Kocaeli, Balıkesir, Antalya, Kırklareli, Mersin, Uşak, Trabzon, Manisa, Kars, Diyarbakır, Düzce ve Edirne yer almaktadır (Başka Sinema, 2020).

\section{Sinema Destekleri ve Euroimages}

Kültür Bakanlığı'nın destekleri Amerikan dağıtım şirketlerinin pazara hâkim olmaya başladığı 1990’li yıllar sonrası başladı, ancak filmlerin yapım maliyetleri ışı̆ı̆ında yetersiz kaldı. 1990'ların ikinci yarısında gelişmeye başlayan bireysel çabalarla yeni bir yapım anlayışı gelişti. "Auteur sinema” alanı bireycilik ekseninde şekillenmeye başlarken, popüler sinema da bu dönemde önemli bir varlık olarak ortaya çıkmaya başlamıştır. Televizyon, reklam ve sponsorluk, film prodüksiyonunun yeni bileşenleri haline geldi (Çelik, 2014: 205-206).

ABD ve Avrupa sinemasıyla teknik, ekonomik ve kültürel ilişki içinde olan Türk Sineması'na 1990 yılından itibaren Eurimages (Avrupa Sinema Destek Fonu)'in etkisi göz ardı edilemez. (Yılmazok, 2010: 21). Türkiye'nin 1990 yılında katıldığı Eurimages'in sağladığ 1 üretim destekleri bu yeni anlayışın yerleşmesinde önemli bir etken olmuştur.

Eurimages Avrupa Konseyi Sinema Fonudur. Hollywood'un küreselleşmeyle birlikte Avrupa'da sürekli artan payı göz önüne alınarak Avrupa Konseyi'nin 26 Ekim 1988 tarihinde sinema 


\section{Sibel Filminin Ekonomi Politiği: Yapım Sürecinin Yansımaları}

destek fonu kurmaya karar vermesiyle Eurimages kuruldu. Türkiye 28 Şubat 1990 tarihinde 18.ci katılımc1 olarak üye oldu. Fon, animasyon, belgesel, uzun metraj (70 dakika üzeri) filmleri desteklemektedir (Y1lmazok, 2010: 89-90). Eurimages'e üye olan ülkeler belli oranda destek olmakta bunun karşıllı̆ında, ortak yapımlar konusunda destek almaktadır.

Türkiye 1990 yılından itibaren bir kaç yıl hariç olmak üzere her yıl yatırdığı aidattan daha fazla destek almıştır. Eurimages'ın son 10 yılda Türk Sinema endüstrisine katkısına bakıldığında 104 Türk filmine 22 milyon Euro destek vererek Türk ortak yapımların \%55'ini desteklediği görülür (Birincioğlu, 2019: 85-90). 1990 sonrası dönemin dört yeni destek kaynağından biri olan Eurimages deneyimi, Film yapım pratiği ile ilgili olarak özellikle, Avrupa sinemasını, teknik yönleri, pazarlama işlerini ve genişletilmiş bütçeleri tanımak açısından Türk sinemasına katkıda bulunmuştur (Yılmazok, 2010: 104).

Euroimages desteği, film yapımcılığı alanında etkinlik oluşturmakta ve özellikle "auteur sinema" için önemli bir seçenek olarak karşımıza çıkmaktadır. Artan sayıda ortak yapımda tanık olunan, uluslararası film yapımında teknik kalitede bir artış ve ilişkilerin gelişmesi olmuştur. Büyük film yapımcısı ülkelerle ortak yapımların başlaması, o ülkelerde filmlerin gösterilmesi izleyici sayısını artırdığı gibi uluslararası bir seyirciye sahip olunmuş ve yönetmenlerin sorumluluğu da artmıştır (Çelik, 2014: 208).

Sosyo-ekonomik altyapısına özgü çeşitli kısıtlar barındırmakla birlikte Türk Sineması'nda da sinema endüstrisinin, endüstrinin tamamlayan bölümlerden üretim, dağıtım ve gösterim ayaklarının- var olduğu, özellikle 1950'li yıllardan sonra oturan bir yapım pratiği ile bu ayaklarda kendi modellerini oluşturduğu görülecektir (Parlayandemir, 2011: 15).

\section{Bağımsız Film Yapım Sürecini Anlamak: Sibel Filmi Örnek Olay Çalışması}

Ana akım sinemanın bile zorlandığı, yeterli destek alamadığı dile getirildiği bir ortamda bağımsız, sanatsal sinema filmlerinin yapılması çok zorlayıcı olmaktadır. Sinema Yazarları Derneği (SIYAD), tarafından 52. SIYYAD Türkiye Sineması Ödülleri arasında sekiz adaylıkla gösterilen (boxofficeturkiye.com, 2020), ilk gösterimi 3 Ağustos 2018'de Locarno Film Festivali'nde gerçekleştirilen Euroimages destekli Sibel filmi çalışmamızın öznesidir.

Betimsel bir çalışma olarak, film yapım sürecinin merkezinde olan profesyonellerle ve çekim atmosferinin içinde (gerek köyün film çekimi için kullanılmasında taraf olan paydaşları, gerekse, filmin yapımında katkısı olan yasal, idari ve ekonomik taraflar) dolaylı ve dolaysız yer alan aktörleri ile yapılan doğrudan görüşmelerle, saha çalışması biçimlenmiştir.

Saha çalışmasında, filmin yapımcısı Marsel Kalvo ile Kasım 2019, yapım amiri Emre Coşar ile Ocak 2020 tarihlerinde İstanbul'da, Köy Muhtarı Avni Köçek ve 1slık dili öğretmeni Orhan Civelli ile Mart 2020 tarihlerinde Kuşköy 'de yüz yüze, yarı yapılandırılmış sorular çerçevesinde derinlemesine görüşme tekniğiyle, ses kaydı alınarak görüşülmüştür. Fransa'da ikamet ettiği için yüz yüze görüşme olanağ1 olmayan filmin yönetmeni Çağla Zencirci ve yönetmen yardımcısı Elif Bağcı ile Şubat 2020, 
Artvin'de çekim yapmakta olan filmin sanat yönetmeni Osman Özcan ile Mart 2020 tarihinde elektronik posta (email) üzerinden görüşülmüştür.

Filmin konusu ve evreni (anlatının içinde yer aldığı ortam; bizim örneğimizde filmin çekim mekânları) gereği, yukarıdakilere ek olarak, filmin çekildiği Kuşköy Muhtarı ve köyün ıslık dili öğretmeni ile de derinlemesine görüşme yapılmıştır. Bu görüşmelerle, çok dilli ve çok kültürlü ortak yapım ekibiyle birlikte, Kuşköy sakinlerinin, ekonomik, sosyal ve kültürel iletişimi de analiz edilmeye çalışılmıştır.

\section{Film Endüstrisine ve Çalışma Koşullarına Dair Değerlendirme ve Deneyimler}

Sinema sadece sanatsal bir faaliyet olmanın çok ötesine geçmiş, birçok farklı birbirine etki eden katmandan oluşan bir endüstridir. Bu endüstrinin olmazsa olmaz koşulları, yapım öncesi, yapım ve yapım sonrası zincirlerini kurumsal temelde oluşturmaktır. Sibel filminin yapımcısı Marsel Kalvo, Türk sinemasının bir sektör olamadığını, yönetmen, senarist, yapımcıların olduğunu ama bir akademiye ihtiyaç duyduklarını söylemektedir; ' 'Bunun dışında sinemanın kapladığı alan genişledi. Sadece sinema filmi yapmak üzerinden konuşamayız artık. Platformlar var, dijital sinema diye bir şey var. Dolayısıyla önümüzdeki günlerde, önümüzdeki senelerde Türkiye'de sinema sektörünü tam olarak oluşturmak lazım" (Kalvo, 2019).

Filmin deneyimli Yapım Amiri Emre Coşar, sinema sektörünün temel sorunu olarak tekelleşmeyi göstermektedir. Büyük şirketlerin insafına bırakılmış sinema sektöründe yeni fikirlere değil, gişe garantisi olarak eğlence içerikli, ana akım filmlere destek verildiğini öne sürmektedir (Coşar, 2020).

Filmin sanat yönetmeni Osman Özcan, film üretiminde yeteri kadar fon ve kaynak olmayışını işaret etmektedir. Bütün bir ülke sinemasının Kültür Bakanlığı Fonu'na endeksli olduğunu ileri sürmektedir. Bu durumun sadece yurt içindeki imkânları kısıtlamadığını, Türkiye'de uluslararası işlerin çıkmasına da engel olduğunu söylemektedir (Özcan, 2020).

Filmin senaristi ve yönetmeni Çağla Zencirci, dünyada olduğu gibi sektörün risk almadan hareket ettiğini, Türkiye'de sinema sektörünün ise gençlerin enerjisini, zamanını, hevesini, yeteneklerini ve azmini sömürdüğunü öne sürmektedir;

" Bu projede bedavaya çalış, önce bir kendini kanıtla, daha gençsin" sözünü şimdiye kadar hiç duymamış bir sinema çalışanı olduğunu sanmıyorum. Her meslek gibi bu da karşıllı̆ı olması gereken bir iş, eve gelen tesisatçıyı "gençsin, önce bir kendini kanıtla" diye bedavaya çalıştırı gönderemezken nedense bunu yönetmeninden stajyerine tüm ekibe son derece doğal bir şekilde uygulayabiliyor bu sektör (Zencirci, 2020).

\section{Bağımsız Sinema ve Sibel Filminin Ekonomisi}

Bağımsız filmler genel ve basit bir tanımlama ile yönetmenin finans desteğini genellikle kendi sağladığı, herhangi bir yapımcıya bağlı kalınmayan, gişe kaygısı gütmeyen, sanat adına yapılan filmler olarak kabul edilmektedir (Ergün, 2019: 28). Sibel bu tanıma uyan bir filmdir. Finansal desteğini 


\section{Sibel Filminin Ekonomi Politiği: Yapım Sürecinin Yansımaları}

Eurimages desteğiyle sağlamış ve yurtiçinde ana akım sinemaya verilen desteği alamamıştır. Filmin yönetmeni Zencirci, bağımsız sinemanın en büyük derdini dağıtım olarak görmektedir. Filmin, film olabilmesi için seyirciye ulaşması gerektiğini söylemektedir.

Nasıl olsa bir ara televizyonda, internette seyrederim diye düşünenlere hak vermemek elde değil, çok uzun süre sinemanın rakibi hatta düşmanı olarak görülen televizyon ve dijital platformlar filmlerin seyirciye ulaşmasını kolaylaştırmış durumda. Ancak seyirci sinema filmini televizyon veya cep telefonunda izlediğinde aslında mercimek çorbasını çatalla içmeye zorlandığını fark edemeyebiliyor. Büyük ekranda son derece açık ve net şekilde gözüken detayları küçük ekranda haliyle seçememiş seyircilerin yorumlarına denk gelmek de mümkün (Zencirci, 2020).

Filmin yapımcısı Kalvo (2019) ise filmin festivallerde ve genelde gördüğü ilgiden memnun olduklarını, ama filmin 35 bin civarında izleyicisiyle ticari beklentileri tam karşılayamadığını ifade etmektedir. Seyircinin Türkiye'de dünyada olduğu gibi sinemadan temel beklentisinin eğlence olduğunu, bunun dişında bir şeyler bekleyen seyirci oluşturmak istediklerini söylemektedir.

Marsel Kalvo, filmin finansmanı film başlamadan Avrupa'da olduğu gibi bankaya koyulduğunda, film ekibinin mutlu olduğunu ve sorun çıkmadığını söylemektedir. Sibel filminin büyük ölçüde bütçesinin Eurimages fonu tarafından sağlandığını, ifade etmektedir;

Toplam bütçe yanılmıyorsam, yaklaşık 300-350 bin avro civarı. Geri kalan bütçe de bu kadardır en az. Yurtdışında post prodüksiyon ve işin geliştirme kısımları yapıldı. Tüm 750-800 bin Avroluk bir bütçesi olduğunu düşünüyorum. Filmin devlet desteği festival desteği olarak oldu. Sinema Genel Müdürlüğü Japonya'ya gittiğimizde, Sibel'le bu desteği aldık biz onlardan. Yaklaşık 30 bin liralık bir destekti. Bunun dışında herhangi bir destek almadık. Çeşitli festivallerde ödül kazandı film bittikten sonra. Mesela Adana'dan 350 bin liralık bir ödül kazandı. O da bir destek olarak filme ilave aslında. Çünkü film çekmek borçlanmak oluyor aynı zamanda. Borçların bir kısmını oradan gelen parayla kapatmış olduk (Kalvo, 2019).

Emre Coşar, böyle filmleri çekebilmenin tek yolunun fon toplamak olduğunu ve yönetmenlerin Fransa'da yaşadığı ve Avrupa Kültür Fonu aracılığıyla filmi çekebildiğini söylemektedir;

Toronto Film Festivali’nde gösterildi Sibel. Damla Sönmez, filmin başrol oyuncusu, filmin her şeyi Damla zaten. Filmin her şeyi olan insana bile Kültür Bakanlığı, destek olmadı. Kendi cebinden ödedi, Damla oraya gitmek için. Bu gerçekten, benim niyazımda, yüz karası bir durum. Orada Toronto Film Festivali'nde temsil ediyor ve gerçekten müthiş bir performans ortaya koymuş. Sinema Genel Müdürü'nün haberi bile yok (Coşar, 2020).

\section{Sinema ve Ortak Yapım}

Filmin yapımcısı Kalvo (2019), sinema filminde çalışma sürelerinin, üzerinde çalıştıkları projeyle doğrudan ilgisi olduğunu söylemektedir. Normalde günde 8-10 saat çalışan bir yapıları olduğu ama bir film yaptıkları zaman ne Cumartesi, ne Pazar, ne mesai saati hiçbir şey kalmadığını ifade etmektedir. İş bitince herkesin mutlu olduğunu, diğer projeye geçmeden önce dinlenecek bir zaman bulmaya çalıştıklarını söylemektedir. 
Bağımsız sinemanın çalışma koşulları ve finansal kısıtlarına dikkat çeken Zencirci (2020), sürekli olarak hızlı ve doğru kararlar almanız gerektiğini ileri sürmektedir. Filmin çok uluslu bir ortak yapım olması nedeniyle çok uluslu bir ekip oluşturulduğunu söylemektedir. Ekipte dört ayrı dilin konuşulduğu, dört ayrı kültürü barındıran bir çekim ekibinin nasıl uyum göstereceğini merak ettiklerini ifade etmektedir. 'Ortak dili sinema olan, parçası oldukları projeyi her türlü zorluğa rağmen severek, benimseyerek, canla başla çalışan bir ekibin, aşamayacağı hiçbir sorun olmadığını bize bu ekip kanitlad1"' demektedir.

Filmin yapımcısı Marsel Kalvo, Çağla Zencirci ve Guillaume Giovanetti'nin yıllarca ziyaret ettikleri Kuşköy üzerine bir senaryo yazdıklarını, kendisine de bu proje için teklif geldiğini söylemektedir. Filmin nasıl ve nerede çekileceği konusunda araştırma yaptıklarını, beş altı kişilik bir ekiple gidilip bakıldığını ifade etmektedir. Son olarak filmin başrol oyuncusu Damla Sönmez, yapım amiri ve mekânlardan sorumlu bir ekiple kendisinin de köye gidip keşif yaptığını söylemektedir (Kalvo, 2019).

Türkiye film endüstrisinde, yurtdışı ilişkileri süregelen ve başarılı işler gerçekleştirmiş olan aktörlerin, dünya film pazarının eğilimleri ile ilgili önemli bir farkındalığının ve üretim göçünden pay almaya yönelik girişimlerinin söz konusu olduğunu söylemek gerekir (Özkan, 2010: 121). Uğur Tanrı̈ver (2010), TC. Kültür ve Turizm Bakanlığı'nın destek politikası ve Eurimages'in katkılarıyla, yeni estetik arayışlar içeren, gişe başarısından çok, sanatsal alanda iddialı filmlerin çoğaldığını, geçtiğimiz yıllarda Türk filmlerinin dünyanın dört bir yanında, Cannes, Venedik, Berlin gibi en saygınları da dâhil 76 festivalde ödül aldığını vurgulamaktadır.

Marsel Kalvo (2019), Sibel filminin dört ülkenin ortak yapımı olduğunu, Lüksemburg’un daha çok teknik katkı sağladığı, Fransa, Almanya ve Türkiye' den ekip katkısı sağlandığını işaret etmektedir. Çekim ekibinin 45 kişi olduğu, sanat, reji, yapım bölümlerinde 4-5 'er kişi olduğunu, yönetmenlerin iki kişi olduğunu ifade etmektedir. Sonradan Fransız yapımcıların da geldiğini, kameraman ve görüntü yönetmeninin Fransız, ses bölümündeki dört profesyonelin Almanlardan oluştuğunu söylemektedir.

Coşar, yapım amiri olarak, yabancılarla daha önce çalışmaktan dolayı deneyimli olduğunu, yabancılık hissetmediğini söylemektedir. Yabancıların görev bilincinin yüksek olduğunu dile getirmektedir;

Bir Alman Görüntü yönetmenimiz vardı. Boyu Damla’ya göre çok uzun olduğu için onu değiştirmek zorunda kaldık. O gitti, yerine Fransız bir görüntü yönetmeni geldi. Hem titizlik hem çalışma şevki, bir kere de hayır de be adam. Çalıların içine atlar, buradan çıkar, zıplar vs. Bir kere kamerayla nehre yuvarlanıyordu. Bizim set ekibinden bir arkadaş havada yakaladı (Coşar, 2020).

Osman Özcan (2020), çok uluslu işlerde çalışarak dünyanın diğer ülkelerinde sinema filmlerinin nasıl çekildiğine dair bilgi sahibi olduğunu, beraber çalışırken ortak çalışma biçimleri ve ortak dil oluşturmak zorunda kaldıklarını, bunun da başka uluslararası projelerde çalışma yeterliliklerini 


\section{Sibel Filminin Ekonomi Politiği: Yapım Sürecinin Yansımaları}

geliştirdiğini iddia etmektedir.

Filmin yapımcısı Kalvo, farklı ülkelerden, bir araya gelmiş, hep birlikte çalışması gereken bazı durumlarda birbirleriyle dil olarak tam anlaşamayan yabancı profesyonellerin bunu yapmasını gözlemlemenin ilginç olduğunu ifade etmektedir;

Herkes İngilizce de konuşmuyordu. Mesela yönetmen bazen Fransızlarla Fransızca konuşuyor, Almanlarla İngilizce konuşuyor, Türklerle Türkçe konuşuyordu. Bunların hepsinin birden anlatılan şeyi anlaması için önce herkes birbiri ile konuşuyor falan. Komik durumlarda oluyordu. Bazen bazı ekiplerin anladığını, bazılarının anlamadığı oluyordu. İlk 3-4 gün öyle zorluklar yaşadık (Kalvo, 2019).

Sibel Filmi’nde görev alan Tirebolu İletişim Fakültesi öğrencilerinden birisi olan Balcı farklı ülkelerden ve kültürlerden insanlarla sinema filmi amacıyla buluşup, böyle bir filmin ortak bir parçası olmanın çok keyifli olduğunu ifade etmektedir; "Sıcak ve samimi ilişkiler kurdular. Yer yer birbirimizden etkilendik. Ki bunlar olumlu etkileşimler iş anlamında. Alman ekip arkadaşlarımız en son iyice Türkçe cümleler kurmaya başlamıştı bile" (Balcı, 2020).

\section{Sinema ve Çekim Şartları}

Filmin yapımcısı Kalvo, filmin çekildiği Eylül- Ekim aylarında bazı günlerin coğrafi şartlardan dolayı zor geçtiğini, Sibel filminin sinematografik sahneleri için sis ortamında çekim yapmayı planladıklarını ama çekim zamanı Sis Dağı’nda bir türlü sisli bir ortam olmadığını söylemektedir;

Tam siste çekim yapmamız gereken zamanda sis yok. Sis oluşturmaya çalışıyorsunuz ama çok geniş ve açık bir alan olduğu için sisi yapmak imkânını çok maliyetli bir şekilde bulabilecektik. O yüzden sissiz çekmeye karar verdik... (Kalvo, 2019).

Film seti birçok farklı görevin iç içe geçtiği onlarca profesyonel sinemacının birlikte çalıştığı bir ortam olduğu için kazalara rastlanmaktadır. Her ne kadar tüm ayrıntılar dikkate alınsa da dağlık, ormanlık bir alanda çekim yaparken kaza yaşanmış ve yapım amiri Emre Coşar'ın diz kapağı kırılımıştır;

Filmde ben Prodüksiyon amiriydim. Her şeyden sorumluydum açıkçası. Ama kendimden sorumlu değilmişim, bir kaza yaşadım ben sette. Ben bu setin amiriyim, hiç bir şey yapmam deyip, kenarda oturursan olmuyor. Ben her tarafa koşturduğum için o kaza başıma geldi. Biz 2200 metre de Sis dağında çekiyoruz. Tam böyle bitmesine yakın, havada kararmış firtına çıktı. Bizimde böyle kocaman ışıklarımız var, onları dikmişiz, gece olduğu için. Işıklar devrilecekti, keşke devrilseydi... Dizim kırıldı sadece... (Coşar, 2020).

\section{Film Yapım Sürecinin Sosyo-Ekonomik ve Kültürel Etkileri: Kuşköy ve Kuşdili’ne Sibel Filmi Katkısı}

Yönetmen Zencirci, telefonun hala işlevini bu bölgede tam yerine getirmediğini, bu nedenle kuşdiline ihtiyaç duyulduğunu bir film anısıyla anlatmaktadır; ' Acil durumlar için son derece pratik bir çözüm, örneğin ön çalışmalar sırasında ormandaki sis yüzünden birbirini kaybeden ekip üyeleri 1slık çalarak birbirlerini bulmuşlardı"' (Zencirci, 2020). 
Filmin yapım amiri Coşar, kuşdilini daha önce duyduklarını ama bu dilin bu kadar kapsamlı ve işlevsel olduğunu gözleriyle gördüklerini anlatmaktadır;

Kuşdili, o zamana kadar öyle bir şey olduğunu biliyorduk ama size anlattığım gibi, köye gittiğimizde ben inanmadım. Dalga geçiyorlar vs. dedim. Sonra yaşadıkça, daha çok gördükçe, mesela orada karşıdaki tepeden biri 1slık çalıyor bizim buradan Kuşdili hocası cevap veriyor. Ne oldu diyorum. "Anam bizi yemeğe çağırıyormuş, gidelim birazdan" diyor. Yok, artık abi diyorum, annesini arıyor. "Anne diyor sen biraz önce 1slıkla ne dedin" diyor? Uzatıyor telefonu bana, annesi "yemeğe çağırdım" diyor. İşte 200 metre ilerdeki adama 1slık çalarak istediği her şeyi yaptırdı. Mesela ceketini çıkart dedi, çıkarttı. Pantolonunu çıkarta kadar geldi olay (Coşar, 2020).

Filmin diğer bağımsız yapımlarla olan ortak özellikleri olsa da, diğerlerinde olmayan başka bir özelliği daha bulunmaktadır. Türkiye'nin de 20 Mayıs 1946 tarihli ve 4895 sayılı kanunla üyeliği onadığı UNESCO "Birleşmiş Milletler Eğitim, Bilim ve Kültür Kurumu"1, 2017 yılı ocak ayında, "Yüzyıllardır Doğu Karadeniz'de 'Kuşdili' olarak da bilinen ıslık dilinin UNESCO Acil Koruma Gerektiren Somut Olmayan Kültürrel Miras Listesi’ne alındığını” ${ }^{2}$ bildirmiştir (UNESCO Türkiye Milli Komitesi). Islık dili konusunda Sibel Filmi toplumsal ve kültürel bir işlevi yerine getirmiş, kültürel miras tanıtımı konusunda, Türkiye ve Avrupa ölçeğinde rol almıştır.

Filmin yapımcısı Kalvo (2019), çekim öncesi üniversite, belediye, il kültür müdürlüğü ile görüşmeler yaptıklarını, köylülerden nasıl destek alabileceklerini, yemeklerin nerede yenebileceğini muhtarla konuştuklarını dile getirmektedir. Köylülerin desteğine karşılık, film ekibi olarak köye yol yaparsak bunun faydası olacağını düşündük ve yaptık demektedir. Filmin bir diğer önemli katkısı ise film yönetmenlerinin Brüksel ve Paris'te UNESCO nezdinde kültür mirası olarak kuşdili için görüşmeler yapmasıdır.

Sibel filminin çekildiği Kuşköy film çekim sürecinde, sosyo-ekonomik ilişkiler kurduğu film ekibinden katkı gördüğünü düşünmektedir. Muhtar Avni Köçek, geçimini çoğunlukla çiftçilikle sağlayan insanlardan oluşan, Karadeniz sahilinden 40 kilometre yamaçlarda kurulmuş bir köy olarak, filmin onlara ekonomik katkı da sağladığını söylemektedir;

Köyde o film çekildiği zaman bir hareketlilik oldu. Bir kaynak oluştu. Kimisi vatandaşın evini kullandı parasını verdi, kiminin tarlasını, çaycıda çay içtiler hesaplarını ödediler, alışveriş yaptılar.. Buradan beş altı tane araç kiralandı mesela araçlar, minibüsler bunlar hep günlük çalıştı para aldılar. O dönem köye giren para yüz bin liranın üzerindedir. Zaten araçların günlüğü 3-4 bin liraydı beş tane araç vardı, zaman oldu altıya yediye çıktı (Köçek, 2020).

Köçek (2020) , köy halkının hem filmde figüranlık yaptığını, hem de köyün içinde ve dışında tüm olanakları film ekibine açtı̆̆ını söylemektedir. Film süresince gelen misafirler için kalacak yer sorunu olduğunu, o nedenle misafirhane yaptırmaya karar verdiklerini ifade etmektedir. Halk Eğitim

${ }^{1}$ UNESCO Sözleşmesi için bknz. http://www.unesco.org.tr/Pages/96/2/UNESCO/erişim tarihi:29.03.2020

${ }^{2}$ Somut Olmayan Kültürel Miras Listesi,http://www.unesco.org.tr/Pages/126/123/UNESCO-\%C4\%B0nsan1\%C4\%B1\%C4\%9F\%C4\%B1nSomut-Olmayan-K\%C3\%BClt\%C3\%BCrel-Miras\%C4\%B1-Temsili-Listesi/erișim tarihi:29.03.2020 


\section{Sibel Filminin Ekonomi Politiği: Yapım Sürecinin Yansımaları}

vasıtasıyla köy çocuklarına ıslık dili eğitimi verdiklerini, bu kültürel mirasın unutulmaması için filmin de katkısı olduğunu ifade etmektedir.

Kuşköy uzun yıllardır Türkiye içinde bilinen bir yer ve kültürel miras açısından önemli bir köy olmasına karşılık, Sibel filmine kadar köylülerin bu ilgiden bir kazanç elde edemedikleri söylenmektedir. Köy halkının artık sinemacı ve habercilere alıştığını, dünyanın her tarafından köyü görmeye insanların geldiği vurgulanmaktadır. Kuşköy muhtarlı̆̆ı bu nedenlerle, köyde çekim yapmak isteyen belgeselci ve televizyon programcılarından, fotoğrafçılardan köy sandığına belli bir miktar para desteği istemektedir. Bunun karşıllğında, onlara rehberlik ve çekimleri için röportaj vermeyi önermektedir.

\section{Sinemanın Toplumsal ve Kültürel Etkileşim Özelliği}

Sinema, dil, din, 1rk, kılık-kıyafet, mekân ve gelenek gibi bu olguların tümünü içine alan bir değişim aracıdır. Bu anlamda ait olduğu toplumun bazen doğrudan bazen de dolaylı yansımasıdır ve toplumla çift yönlü bir ilişki içerisindedir. Sinema içinde bulunduğu toplumun koşullarından soyutlanamaz, toplumun içinden gelen bir öğedir ve toplumla sürekli karşılıklı bir iletişim içerisindedir (Sevinç, 2013: 1).

Sinema yalnızca bir dış gerçekliği yansıtmaz/eğip bükmez, aynı zamanda toplumsal yaşamın önüne muazzam bir olanaklar evreni serer. Bu bakımdan sinema çoğu zaman, değişen toplumsal biçimlerle yapılan bir deney niteliği taşır (Diken ve Laustsen, 2011: 47). Sinema sosyal söylemleri kullandığı, yeniden ürettiği ve zaten kendiliğinden sosyal bir söylemsel eylem olduğu için temelde toplumsaldır (Ryan, 2015: 81).

Sinemanın, farklı toplumların kültürleri ve yaşam biçimleri hakkında izleyicilerine bilgi veren, toplumlar arasında kültür alışverişini sağlayan, eğitici yanı oldukça yüksek bir sektör olması nedeniyle film ekibi ile çekimin yapıldığı köy ahalisi arasında özel bir ilişki kurulmuştur;

Zaten her Anadolu şehrinde böyledir ama bizim muhtar böyle sevecen bir insandı. Çok sert ama o engeli aşınca, baba gibi davrandı bize. Böyle gelip başta ilgilenmiyormuş gibi davranıp sonra monitörün başından kalkmadı hiç. Gerçekten her konuda yardımcı oldular. Akşamları evlerinde mi ağırlamadılar, çok alakalılardı gerçekten (Coşar, 2020).

Filmin Karadeniz'in kapalı bir kırsal köyünde çekilmesi, film ekibinin ise çoğunluğunun başta İstanbul olmak üzere yurtdışı kökenli olması nedeniyle farklı etkileşimler olmuştur. Yönetmen yardımcısı Elif Balcı, köyün yerlisi ve ekibin şoförlüğünü yapan birisine eşi için tavsiyede bulunduğunu, bir kaç gün sonra, servis şoförünün kızının onu ziyarete geldiğini, babasının annesine hanım diye seslendiğini, eşinin de çok hoşuna gittiğini, çocukların da bu durumu görünce mutlu olduğunu bunun için sarılıp, Elif Balcı'ya teşekkür ettiğini ifade etmektedir (Balcı, 2020).

Kuşköy muhtarı Avni Köçek, tüm film çekimleri boyunca film ekibiyle yakından 
ilgilendiklerini, film çekimlerini gözlemlediklerini söylemektedir. Ona göre sinema filmi yapmak, dışardan göründüğü gibi olmayan, çok zor ve disiplinli bir süreçtir;

Çok incelik isteyen bir meslek. Sakin olmak gerek. Talimat verdiği zaman nefes bile almıyorlar filmde en ufak bir şey olursa diye. Onların ses sistemlerine her şey yansıyormuş. Benim evde bir hafta on gün ev içerisinde çekim yaptılar komut veriyor işte tabi yabancı dil olduğu için ben çoğunu anlamıyorum ama çıt çıkmıyor. Çok zor olduğunu gördük gel geç değil zor bir şeymiş (Köçek, 2020).

Film ekibine Islık dili konusunda uzman öğreticilik yapan Orhan Civelek, farklı kültürde, yabancı insanlarla çalıştıklarını, dilleri ayrı olsa da gönüllerin iyi olduğunu söylemektedir;

Farklı diller konuşan, farklı milletlerden insanlarla çalışmak çok iyi. Her şeye teşekkür edebilen çok saygıdeğer insanlar olduklarını keşfettik. Dillerimiz ayrı olsa da gönül olarak çok iyi olduklarını fark ettik. Sinek bile daha uçmuyor havada filmin zor olduğunu öğrendik. Televizyon izlemek çok kolay ama çekmek çok zormuş. Şurada bir çay içme sahnesi var inanın akşama kadar denendi (Civelek, 2020).

Yapımcı Marsel Kalvo (2019), filmin ilk gösteriminin Kuşköy'de yapıldığını, köylülerin çok memnun kaldığını ifade etmektedir. Bazı endişeleri olduğunu, filmde bir takım sorunları anlattıklarını ama köylülerin, filmin gerçekleri anlattığını anladığı ve kimsenin kötülenmediği için, memnun kaldıklarını söylemektedir.

Filmin senaristi ve yönetmeni Çağla Zencirci (2020), çok memnun olduklarını, zor bir coğrafyada, hava koşullarını tahmin edemediklerini ama Kuşköy’lülerin köye ayak bastıkları günden çekimin son gününe dek verdikleri destek ve ardından filmin başarılarından duydukları gururla her zaman yanlarında olduklarını söylemektedir.

\section{Sonuç}

Türkiye'de günümüzde, sinema sektöründe üretim yapılmakta ve televizyonlar için çekilen dizilerden kâr elde edilmektedir. Üretim sayesinde istihdam artmakta ise de sinemada kurumsal bir yap1 oluşturulamadığı ve sektör olamadığı için, sinemayı oluşturan tüm bileşenlerin her biri ayrı bir sorun içermekte, bu sorunları çözmek için ayrı bir çaba gerekmektedir (Saydam, 2018).

Milliyet Yazarı Nil Kural'ın (2019), 'şaşılacak kadar ustalıkla anlatılmış, olgun ve feminist bir film. Film, bir kadının özgürleşme mücadelesini gösterirken kurduğu görsel dil ve atmosferle takdiri hak eden yılın en iyi yerli yapımlarından", diye nitelendirdiği Sibel, Karadeniz'de konuşma özürlüsü olan genç bir kızın, içinde yaşadığı çetin doğa koşullarıyla birlikte, kendi halkı tarafından nasıl dışlanabileceğini gösteren gerçekçi bir film özelliği taşımaktadır.

Çalışma sorunsalımız, Sibel filminin yapım sürecinin, yapım aşaması, film bütçesi, çekim takvimi, profesyonellerin nicel/nitel özellikleri ve çekim atmosferinin fiziksel/ruhsal koşulları ile kısıtladığı koşullarla biçimlenen oldukça zahmetli bir süreç olduğudur. Bu çalışma, sorunsalımızı doğrulamıştır. 


\section{Sibel Filminin Ekonomi Politiği: Yapım Sürecinin Yansımaları}

Ortaya çıkan filmin, yapım koşulları filmin teknik, estetik, sanatsal, ekonomik tüm sonuçlarıyla ilişkilidir. Film bütçesinin Eurimages tarafından karşılanan büyük bölümü ile film ancak çekilebilmiş, kurgulanmış ve gösterime sunulmuştur. Ne var ki, İstanbul, Ankara, İzmir ve filmin çekildiği yer olan Giresun haricinde gösterim şansı büyük sinema zincirlerinin sinema salonlarında ya hiç olmamış ya da bir iki seansla sınırlı kalmıştır. Bu nedenlere bağlı olarak, Sibel filmi, Box Office Türkiye 2019 yıllık raporuna göre 33.725 sinema izleyicisi tarafından izlenmiş ve 410.163 TL hasılat yapmış, gösterilen 622 film arasından 147.sırada yer almıştır.

Filmin Türkiye çapında az sinema salonunda gösterilmesi, izleyici ve gişe hasılatını olumsuz yönde etkilese de, Giresun'da seyircinin kendi yörelerinde çekilen filmi görmeye gitmemeleri, sorunun sadece ekonomik olmadığını göstermektedir. Dolayısıyla mesele sadece "ekonomi politik" değil bir o kadar da kültürel gözükmektedir. Sinema seyircisinin sinema salonunda film izlemeye gitmeyip, sayısal internet ve paralı televizyon kanalları gibi farklı mecralar üzerinden arayışlara yöneldiği gözlemlenmektedir.

Film bütçesinin sınırlı olması nedeniyle, 45-50 kişi arasında değişen ekip, birçok işi amatör bir şevk ve istekle, köylülerin de desteğiyle başarabilmiştir. Bütün bunlar yazılı olmayan, sıra dışı ilişkiler sonucudur.

Gerek filmin çekildiği, Karadeniz'in engebeli arazisi ve yol açtığı zorluklar, gerekse hava durumu film çekimlerini doğrudan etkilemiştir. Engebeli arazi yüzünden, Sis dağı çekimlerinde 1şıklar firtına ve rüzgâr yüzünden tehlike arz etmiştir. Bunu engellemeye, 1şıkların devrilmemesi için çaba gösteren yapım amiri kaza geçirmiş ve diz kapağı kırılmıştır. Yine bazı çekimlerin sis altında çekilmesi gerekirken, hava durumu buna engel olmuştur. Bu sahneler daha sonra post prodüksiyon denilen, kurgu aşamasında görsel efektler aracılığıyla, istenilen sinematografik etkiye dönüştürülmeye çalışılmıştır.

Yapım süreci sonunda ortaya çıkan kültürel ürün, fikir aşamasından başlayarak tüm faktörlerden etkilenmiştir. Islık dilinin film için ana unsurlardan birisi olması, başrol oyuncusunun film boyunca 1slık dili ile konuşmak zorunda kalan genç bir kadını canlandırması nedeniyle, bu dili öğrenmesi gerekmiştir. Islık dilini köyde öğreten ' Islık dili' 'öğretmeni tarafından özel dersler verilmiştir. Bu aşamada bazı sahnelerdeki ıslık sözcüklerinin eksik yapılması sonucu, sonradan stüdyoda bu sesler dublajla eklenmiştir. Film senaryosu, oyunculara yeni beceriler kazandırmıştır.

Sonuçta, filmin etkisi nedeniyle ıslık dilini öğrenmek isteyen daha fazla sayıda ziyaretçi yurt içi ve yurt dışından köyü ziyaret etmeye başlamıştır. İlk defa bu kadar kalabalık bir film ekibini ağırlayan Kuşköy sakinleri, misafirhane yaptırmaya karar vermişlerdir. Film ekibi, çekim takvimi boyunca yakından iletişim ve etkileşime girdiği köy halkından hem etkilenmiş, hem de onları davranışlarıyla etkilemiştir. 


\section{Kaynakça}

Akser, M. (2015). Turkish independent cinema: between bourgeois auterism and political radicalism. D. Baltruschat, \& M. P. Errickson içinde, Indipendent Filmmaking Araound The Globe (s. 131148). Toronto: University of Toronto Press.

Balcı, E. (2020, Şubat 20). (M. Coşkun, Röportaj Yapan)

Başka Sinema. (2020, Mayıs 8). Türkiye. Mayıs 8, 2020 tarihinde http://www.baskasinema.com/salonlar/ adresinden alındı

Birincioğlu, Y. D. (2019, Haziran). Popülist söylemin perde arkası: 5224 Sayılı Sinema Filmlerinin Değerlendirilmesi Ve Sinıflandırılması İle Desteklenmesi Hakkında Kanun'a dair değerlendirmeler. Moment Dergi-Hacettepe Üniversitesi İletişim Fakültesi Kültürel Çalışmalar Dergisi, 75-98. doi:ISSN: 2148-970X

Bordwell, D., \& Thompson, K. (2009). Film sanatı (1.Baskı b.). (E. Yılmaz, \& O. S. Emrah, Çev.) Ankara: De Ki Basım Yayım Ltd. Şti.

boxofficeturkiye.com. (2020, Ocak 14). 52-siyad-turkiye-sinemasi-odulleri-adaylari-belli-oldu. Mart 5, 2020 tarihinde https://boxofficeturkiye.com/haber/52-siyad-turkiye-sinemasi-odulleri-adaylaribelli-oldu--2451 adresinden alındı

Civelek, O. (2020, Mart 8). (M. Coşkun, Röportaj Yapan)

Clarke, J. (2012). Sinema akımları: Sinema dünyasını değiştiren filmler. (O. Gayretli, Dü., \& Ç. E. Babaoglu, Çev.) İstanbul: Kalkedon Yayınc1lı. doi:isbn: 978-605-4511-64-8

Coşar, E. (2020, Ocak 29). (M. Coşkun, Röportaj Yapan)

Dağtaş, E., Aydın, N., \& Yılmaz, Ç. (2018, Ocak). Sinemanın ekonomi poitiği: 2016 yılı verileri üzerine bir değerlendirme. TRT Akademi, 3(5), 186-218.

Diken, B., \& Laustsen, C. B. (2011). Filmlerle sosyoloji (2.Basım b.). (Ö. Çelik , Dü.) İstanbul: Metis Yayınları. doi:ISBN-13: 978-975-342-762-3

Ergün, E. (2019, Haziran). 1990 sonrası türk sinemasında film anlatı yapılarına karşılaştırmalı bir bakış. İstanbul. Mart $\quad$ 5, $2020 \quad$ tarihinde https://acikerisim.iku.edu.tr/bitstream/handle/11413/5345/Ezgi\%20Erg\%C3\%BCn\%20YL\%2 0Tez.pdf? sequence $=1 \&$ isAllowed $=$ y adresinden alınd 1

Fener, S. (tarih yok). Nisan 29, 2020 tarihinde Antrakt sinema: http://www.antraktsinema.com/makale.php?id=773 adresinden alınd 1

Kalvo, M. (2019, Kasım 16). (M. Coşkun, Röportaj Yapan)

Köçek, A. (2020, Mart 8). (M. Coşkun, Röportaj Yapan)

Kural, N. (2019, Şubat 23). Islıkla isyan eden bir kadın. Mart 5, 2020 tarihinde milliyet.com.tr: https://www.milliyet.com.tr/yazarlar/nil-kural/islikla-isyan-eden-bir-kadin-2831462 adresinden alınd 1

(2020). Kültür endüstrileri destek ve teşvik rehberi. TC Kültür Bakanlığı.

Liman, A. S. (2009). Türk sinemasında çekim sonrası üretime dayalı teknik altyapı sorunları ve bunun sinema sanatına etkileri. İstanbul, Türkiye. Şubat 12, 2020 tarihinde https://tez.yok.gov.tr adresinden alınd 1 


\section{Sibel Filminin Ekonomi Politiği: Yapım Sürecinin Yansımaları}

Midilli, S. (2016). Sinemada alternatif gösterim olanakları: Başka sinema'lar mümkün mü? International Academic Research Congress (S. 1529-1536). Antalya: Pegem Akademi. doi:eISBN 978-605-318-752-3

Özcan, O. (2020, Mart 4). (M. Coşkun, Röportaj Yapan)

Özen, E., \& Çelenk, S. (2006, Haziran). Sinema endüstrisinin ekonomik yöndeşme eğilimleri: Hollywood örneği. Türkiye. Mart $14 \quad 10, \quad 2020$ tarihinde https://www.academia.edu/6835063/Sinema_End\%C3\%BCstrisinde_Y\%C3\%B6nde\%C5\%9F me-_Hollywood adresinden alınd1

Özkan, E. T. (2010). İstanbul'da kültür ekonımisine yön veren dinamikler (1.Bask1 b.). İstanbul: İstanbul Bilgi Üniversitesi Yayınları. doi:ISBN 978-605-399-177-9

Parlayandemir, G. (2011, Haziran 1). Türk sinemasının endüstriyel yapısının Amerikan sinemasının endüstriyel yapısıyla karşılaştırmalı olarak incelenmesi. İstanbul, Türkiye. Şubat 12, 2020 tarihinde https://tez.yok.gov.tr/UlusalTezMerkezi/tezSorguSonucYeni.jsp adresinden alındı

Ryan, M. (2015, Sonbahar). Sinema politikaları: Söylem, psikanaliz, ideoloji. (H. Erkılıç, Dü.) Sinecine(6(2)). Şubat 23, 2020 tarihinde https://dergipark.org.tr/tr/download/article-file/671345 adresinden alındı

Saydam, B. (2018). 2017'de bağımsız Türk sinemasının genel görünümü. Türkiye. Şubat 12, 2020 tarihinde https://www.tsa.org.tr/tr/yazi/yazidetay/384/2017\%E2\%80\%99de-bagimsiz-turksinemasinin-genel-gorunumu adresinden alınd 1

Sevinç, Z. (2013, Haziran). Yeni Türk sineması: 2000 sonrası Türk sinemasına sosyolojik bir bakış. Kütahya. Şubat 22, 2020 tarihinde Ulusal Tez Merkezi (https://tez.yok.gov.tr) adresinden alındı

Tüzün, S. (2011, Haziran 1). Küresel-yerel tartışmaları bağlamında "RECEP IVEDİK”. İstanbul, Türkiye. Şubat $11, \quad 2020 \quad$ tarihinde https://tez.yok.gov.tr/UlusalTezMerkezi/tezSorguSonucYeni.jsp adresinden alınd1

Tzioumakis, Y. (2006). American independent cinema. Edinburgh: Edinburgh University Press Ltd. doi:ISBN-13 9780748618675 (paperback)

Uğur Tanrı̈ver, H. (2010). Türkiye'de film endüstrisinin konumu ve hedefleri. İstanbul, Türkiye. doi:ISBN 978-9944-60-923-4

UNESCO Türkiye Milli Komitesi. (tarih yok). UNESCO hakkında. Mart 29, 2020 tarihinde http://www.unesco.org.tr/Pages/96/2/UNESCO adresinden alınd1

Yıldırım, K. (2010 ). Nitel araştırmalarda niteliği artırma. İlköğretim Online, Cilt 9(Sayı 1), 79 - 92.

Y1lmazok, L. (2010, Güz 1 (2)). Turkish films co-produced within Europe: The story after twenty years' experience in eurimages. Cinesine. Şubat 20, 2020 tarihinde https://dergipark.org.tr/tr/download/article-file/707540 adresinden alındı

Zencirci, Ç. (2020, Şubat 18). (M. Coşkun, Röportaj Yapan) 